Western University Scholarship@Western

Education Publications

Education Faculty

2012

\title{
Postcolonial Entanglements: Unruling Stories
}

Veronica Pacini-Ketchabaw

Western University, vpacinik@uwo.ca

Follow this and additional works at: https://ir.lib.uwo.ca/edupub

Part of the Early Childhood Education Commons

Citation of this paper:

Pacini-Ketchabaw, Veronica, "Postcolonial Entanglements: Unruling Stories" (2012). Education Publications. 42.

https://ir.lib.uwo.ca/edupub/42 
Article to appear in 'Troubling Multiculturalism in Child and Youth Care Theory and

Practice,' special issue in Child and Youth Services (2012) Volume 33:3-4, 303-316.

\title{
Postcolonial Entanglements: Unruling Stories
}

\author{
Veronica Pacini-Ketchabaw ${ }^{1}$
}

\begin{abstract}
In this article, I use Donna Haraway's philosophy to think about postcolonial encounters between different species. I follow entangled stories of the deer/settler-child figure to trouble colonialisms and untangle the histories and trajectories that we inhabit with other species through colonial histories. I shy away from generalizations and instead grapple with complexities that ordinary stories bring as I attempt to engage in nonhegemonic versions of childhood studies.
\end{abstract}

\footnotetext{
1 This article emerged from my readings of Donna Haraway and, importantly, from my many long conversations with graduate students Denise Hodgins, Fikile Nxumalo, Kathleen Kummen, Deborah Thompson, Scott Kouri, Vanessa Clark, and Carol Rowan.
} 


\title{
Postcolonial Entanglements: Unruling Stories
}

\author{
Veronica Pacini-Ketchabaw
}

The child care centre where I work on Vancouver Island, British Columbia, is located next to a forest that is home to many indigenous species, including mule deer. The children and educators at the centre love this forest and we often take nature walks through it. The sounds, smells, and sights we encounter on these walks spark many conversations throughout the day. To our delight, the deer who live in these woods visit our centre regularly, approaching the chain link fence that separates them from the children. The fence is a child care licensing requirement, ostensibly to restrain the children for their own safety; in reality, it restricts the deer more than it does the children, because the children, with adult supervision, can pass through a gate to the other side.

Mature deer visit the centre in the fall and winter; in the spring we greet the new fawns with excitement. We adults remind the children not to startle the deer; when a deer approaches the fence, we ask those children who are in a different room to come quickly to the window; together, we watch as the deer walk the length of the fence; we pay attention to their every movement. We are all deeply interested in the deer.

I am curious, too, about the deer's interest in coming close to the fence to look at us, to look at the children. I wonder who is watching whom and what the risks are of the intersecting gaze. What is this relationship about? What happens when two species with different but entangled histories come together? What kinds of relations are being shaped, right at that moment, between indigenous and settler ${ }^{2}$ species? As the deer and the children look at each other, histories are enacted, lives are changed, and new possibilities are generated for responding to each other. The responsibilities we have toward the deer we look in the eyes are real and actual; they shape us as beings and require a response. We cannot innocently ignore the ways in which the deer's lives - and our own - are shaped by our intra-actions. We are in the middle of who the deer are and the deer are in

\footnotetext{
2 The term 'settler' refers to, as Deborah Bird Rose (2004) notes, "the conquerors and their descendants" (p. 2). It implies invasion or occupation of lands where people were already residing; in particular, it refers to settler colonialism and European colonial expansion.
} 
the midst of who we become. For example, in the moment of the gaze, the politics of wild animals might change. Food economies might shift as we encounter the deer face to face. ${ }^{3}$ And, as these systems are altered, we and the deer are changed forever. Does this coshaping offer possibilities for learning how to live and to become together in less violent, more "equitable" ways? What can we learn from these encounters about life in a postcolonial state ${ }^{4}$ ? How has this encounter shaped, and been shaped by, colonial imaginaries? How might this encounter undo us as well as our practices with young children?

For some time now, cultural differences and diversity have been topics of interest in child and youth studies. Much has been written about difference and diversity, both in academic circles and discussions of practice. As an example of the latter, BC's Early Learning Framework (Government of British Columbia, 2008) includes the following statement to describe the importance of social responsibility and diversity when working with young children:

Children benefit from opportunities to build relationships, to learn about their own heritage and culture and that of others, and to recognize the connection between their own actions and the wider world. These activities help build the ethical foundation for social and environmental health and well-being, now and in the future. (p. 33)

Academics, in recent years, have challenged colonialisms and neocolonialisms, including Canada's colonial history and contemporary neocolonial rationalities and mentalities within the context of Canadian childhood (de Finney, Dean, Loiselle, \& Saraceno, 2011; Nxumalo, Pacini-Ketchabaw, \& Rowan, 2011; Pacini-Ketchabaw, 2007, 2010; Pacini-Ketchabaw, White, \& Armstrong de Almeida, 2006). The intention of much of this literature has been to situate contemporary childhoods within colonial enterprises and to engage in confronting, challenging, and undoing the dominative and assimilative

\footnotetext{
${ }^{3}$ Levinas's (1969) ethics of face-to-face relations makes us answerable to the call of the other: "In the faceto-face relationship the individual experiences being obligated before the Other, and is called to response and responsibility in relating to the person who is other than himself or herself' (Cook \& Young, 2004, p. 343). I argue that this ethics can be extended to human-nonhuman relations (see Rose, 2004).

${ }^{4}$ My use of the term 'postcolonial state,' both here and throughout, does not denote the end of colonization. I use the term to be attentive to colonized, racialized, and gendered histories entwined with state formation (see Jiwani, 2006; Razack, Smith, \& Thobani, 2010).
} 
forces of colonialism as a historical and contemporary process. Many questions have been addressed, including these: How do racial and economic hierarchies and categories from colonial pasts persist in today's social, political, and material landscapes within the context of childhood? How are neocolonialisms activated in Canadian childhoods? And, how do they shape their spatialities and temporalities? These questions remain extremely important. In the Canadian context, the effects of colonization bleed into the present in many ways, particularly in assimilation policies and ongoing material and cultural appropriations of Canada's Indigenous peoples.

One commonality of these texts is their focus on human relations - how humans come together, what happens when differently positioned humans come together, how differences among humans function in always already differential power dynamics, and so on. These discussions have been immensely helpful in a field that for too long has paid little attention to the intricacies and subtleties of colonialisms and neocolonialisms (de Finney, Little, Skott-Myhre, \& Gharabaghi, 2012). However, when I sit with the children to watch the deer through the child care centre's window, I am aware that this relationship involves much more than just an innocent look. What histories are we inhabiting here? What's going on through/within our act of looking?

In this article, I want to extend the important conversations that have shifted how we think about children and social justice by exploring the kinds of encounters I related in the opening paragraphs - encounters among humans and nonhumans in postcolonial states. What happens when human and nonhuman bodies come together? Through this inquiry, I follow a curiosity in child and youth studies around nonhuman others (see Pacini-Ketchabaw, in press, submitted; Pacini-Ketchabaw, Kummen, \& Thompson, in press; Skott-Myhre, 2012). By looking at human/nonhuman entanglements, I argue that the troubling of multiculturalism and colonialisms (the topic of this issue) is not limited to humans, and I engage with the following question: How can we conceive a politics for troubling colonialisms in which human individuals are not necessarily the central players, but players among nonhuman others?

To engage in this politics, I grapple with practices and stories that are both political and mundane, as is the story above. I hope that through these ordinary stories I can offer a challenge for responding to our colonial histories. I draw on biologist-philosopher 
Donna Haraway's (1995) "bag-lady story telling" in which she notes that "stories do not reveal secrets by heroes pursuing luminous objects across and through the plot matrix of the world" (p. 71); instead, they put "unexpected partners and irreducible details into a frayed, porous carrier bag" (p. 71). In the process, bag-lady stories "do not have beginnings or ends; they have continuations, interruptions, and reformulations" (p. 71). In other words, these stories build worlds. Affrica Taylor (2011) explains this approach to story telling as one that "grapple[s] head-on with knotty differences - not to minimize or discount them, not to try and assimilate them, not to reduce them to exclusively human concerns, but to let them be "irreducible"” (p. 5). The key, she asserts, is "embarking upon the practice of 'loosening up' and 'untangling' the knots, so that [we] can 'pull out the threads' and trace their connections" (p. 5).

Through story telling, Haraway (2008) has been exploring the figure ${ }^{5}$ of a human/dog companion-species to think about what she calls natureculture entanglements:

We are in a knot of species coshaping one another in layers of reciprocating complexity all the way down. Response and respect are possible only in the knots, with actual animals and people looking back at each other, sticky with all their muddled histories. Appreciation of the complexity is, of course, invited. But more is required too. (2008, p. 42, emphasis added)

Following Haraway's call, Taylor (2011), working in early childhood studies in Australia, traces the postcolonial figuration of wombat/settler-Australian by unravelling "some of the 'sticky knots' that they present and which are quite specific to postcolonial Australian commonworlds” (p. 3). Using a similar approach, Mindy Blaise, an early

\footnotetext{
${ }^{5}$ Haraway (1997) uses figures as reclamations that have "real" meanings, a kind of personification and, simultaneously, a making of knowledge. Figures are not about representations or significations, but they can be inhabited "to map universes of knowledge, practice and power" (p. 11). Figures, Haraway (1997) says, "involve at least some kind of displacement that can trouble identifications and certainties"; they "can be condensed maps of contestable worlds" (p. 11). Claudia Casteneda (2002) writes:

This concept of figuration makes it possible to describe in detail the process by which a concept or entity is given a particular form-how it is figured - in ways that speak to the making of worlds. To use figuration as a descriptive tool [not as representation] is to unpack the domains of practice and significance that are built into each figure. A figure, from this point of view, is the simultaneously material and semiotic effect of specific practices. Understood as figures, furthermore, particular categories of existence can also be considered terms of their uses - what they 'body forth' in turn. Figuration is thus understood here to incorporate a double force: constitutive effect and generative circulation. (p. 3)
} 
childhood scholar who works in Hong Kong, maps relations between dogs in prams in postcolonial Hong Kong. Blaise wrestles with the notions of context, difference, and complexity and emphasizes the practice of making the familiar unfamiliar by taking a contact-zone perspective. She invites us to attend to the coshaping that happens between species in ordinary events and to make room for the articulations and entanglements that exist across borders. Miriam Giugni (2011), in Australia, pays attention to the chicken/settler-child figure. Giugni grapples with activism, getting entangled in the proposition of doing activism by becoming relational and generative, by gathering and questioning. She says, let's engage in "an expansive and complex practice" of taking our relationships (with human and nonhuman others) seriously (p. 6). These three scholars collectively, following Haraway's work, question how to engage in an inclusive relational ethic that is less humancentric and more worldly (Taylor, Blaise, \& Giugni, 2013), how to grapple with the dilemmas that differences bring, and how to "become with." I see these directions as the "more that is required" that Haraway asks for in the quote above. I find this approach helpful for my own mappings of natureculture entanglements specific to postcolonial Canada. In these mappings, I shy away from generalizations and instead grapple with some of the complexities that mundane stories bring.

In what follows, I map relations between indigenous deer and settler Canadians. I situate this mapping in the specific relations and entanglements of the lives of young children and of deer on Vancouver Island to argue that we need analyses of postcolonial entanglements that consider all partners and relational knots. As Haraway (1997) notes, "social relationships include nonhumans as well as humans as socially ... active partners" (p. 8). She reminds us that "all that is unhuman is not un-kind, outside kinship, outside the orders of signification, excluded from trading in signs and wonders" (p. 8). Through the deer/settler-child figure, I hope to offer a renewed politics for child and youth care that engages with colonialisms by looking at the entanglements of human and nonhuman others in postcolonial spaces.

Thinking with the deer/settler-child figure allows me to engage in the politics of postcolonial relations - and in the kinds of lives that postcolonial relations organize - in the nodes and knots of living together in postcolonial spaces like Vancouver Island. I am 
curious about the ways in which these relationships, and the power-knowledge relations they embed, materialize certain worlds and not others. I wonder about the kinds of worldings, as Haraway $(1997,2008)$ calls them, that are generated. I am interested in the coshaping that takes place in encounters like the ones I related above and the ones below. Referring to dogs, Haraway (2008) says that nonhuman species "have not been unchangeable animals confined to the supposedly ahistorical order of nature. Nor have people emerged unaltered from the interactions. Relations are constitutive" (p. 62). This means that all encounters somehow matter because it is through these encounters that we emerge as "historical beings, as subjects and objects to each other, precisely through the verbs of their relating" (p. 62).

\section{Deer/settler-child entanglements}

Black- and whitetail deer and their hybrid descendants, including mule deer, have been living in North America for more than two million years. Mule deer are plentiful in many parts of Vancouver Island. Although much of their value today is aesthetic and recreational, deer meat was an important part of the First Nations diet for thousands of years and, in many cases, still is. Deer were also an important link between First Nations and white Europeans. Not only did the European colonizers depend on deer meat to survive, they also "killed many in order to provision trading posts and also exported deer hides with other furs. In the late 1800s, market hunters supplied mining camps with deer meat" (British Columbia Ministry of Environment, Lands, and Parks, n.d., p. 5). Deer have taught us visitors in the territory we call North America something about this land. They have also participated in our capital accumulation and empire building. Since World War II, recreational hunting and tourism have boosted the value of deer in the North American economy to millions of dollars. Today, we have a profitable hunting industry built around killing deer, and we also showcase them to tourists who are delighted to see frightened deer in our beautiful forest parks.

Our relationship with the deer becomes a bit more "testy" when we encounter them in our gardens. Simply put, we don't like deer to eat the flowers and vegetables we have worked so hard to grow after long, bare winters. Living beside a ravine, I encounter these creatures all the time in my little garden. They love the roses and, even more, my 
neighbours' figs. There is always someone in the neighbourhood who comes to the rescue and ensures that the deer go back to the ravine where they belong: in nature. Some of the neighbours have enclosed their gardens, or parts of them, with fences to deter unwanted visitors.

Fences, children, and deer form interesting assemblages. For example, the fence that separates the child care centre from the deer becomes a material/semiotic marker of hyperseparation between the "civilized" domesticated world of the child and educator on one hand and the "uncivilized" indigenous world of the deer on the other. On one side of the fence, we find the manicured child care centre playground, which has been recently renovated to meet "natural playground" stipulations. On the other side, the grass grows wild and huge pine trees provide shade. As Lesley Instone (2010) notes, "the fence is an arresting delineation of native/non-native, introduced/indigenous, colonial/postcolonial" reflecting material and discursive practices of "neat/messy, familiar/unfamiliar, accessible/inaccessible" for the children, educators, and deer (p. 93). The fence does the work of boundary maintenance - although these boundaries become blurry, as I explain later.

These stories might imply that our relationship with deer is sometimes violent. Foucault (1977) would tell us, however, to look at points of resistance. Better yet, we could look at our coshaping (Haraway, 2008) with the deer. In my research for this article, I came across the following quote on an American hunting website that explains how we and deer emerged together:

The early and ongoing colonization of America did little to diminish the whitetail's presence. To the contrary, it helped increase and broaden deer populations. Before colonization, our forests were large, dense and contiguous. As humans cleared the land, deer moved into diverse new habitats and flourished. Deer fed and mated in open fields and cutovers. Nearby woodlands provided cover and warmth. Today, as the sub-urbanization of America continues, whitetail herds continue to grow and thrive in small, broken habitats. (Outdoor Adventures Network, 2012, para. 2)

These stories make me wonder about living with difference. How are different species entangled together? How do we shape each other? Can this shaping be done in a 
respectful way? The deer who look at us (and we who look at the deer) are part of colonial conquest, trade, economies, ecologies, resistances, tourism, and entertainment (Haraway, 2008). How do we learn to live together in this "knotty" relation in less violent ways? Following Haraway (2008), I suggest that we take these questions and complexities seriously as we think about our own demands on the Other, on those whose lands and lives we have come to impose ourselves. Let's ask how we got here together and how we have shaped each other's lives and histories.

Many stories speak specifically about the entanglement of children's and deer's lives. Walt Disney's Bambi (1942) provides a productive space to think about the place deer occupy in the North American settler imaginary, and it is through this film that many North American children have established an affectionate relationship with deer. Hastings (1996), in "Bambi and the Hunting Ethos," describes the film's affectionate tone:

[The film] presents an idyllic forest without active carnivores. One could argue that the movie's real theme is love in all its varieties, as the opening song, "Love Is a Song" suggests. Bambi opens with an evocation of maternal love, as the newborn fawn nestles against his mother's side while the smaller animals gather to greet the "young prince." The early part of the film shows Bambi's first year of life and primarily develops the relationship between mother and fawn, along with childhood (same-sex) friendships. The second part of the film, following the death of Bambi's mother, develops a more mature love theme, as Bambi and his friends each pair off with an appropriate female, and his developing relationship with the doe Faline takes center stage. At the end, the cycle of love relationships is completed as Bambi and Faline become parents themselves. The peaceable kingdom of the opening is recapitulated as Bambi's twin fawns become the focus of adoration by the smaller animals, and the film ends with Bambi's father ceding the rule of the forest to his son. (para. 3)

This film is far from innocent, however, and we know that how children relate to troubling messages in films like Bambi is not straightforward (Tobin, 2000). In Bambi, as in many other Disney stories, we find a gestating space of corporate interests, colonization of desires, idealized versions of North America, racialized and gendered 
discourses, and much, much more (Kasturi, 2002). Since Bambi, hunting will never be seen the same way. And this, of course, brings material consequences for those who depend on deer as an important part of their diets. Whose meals are more important? These are the kinds of "knotty" spaces that Haraway (2008) suggests we take head-on instead of just analyzing them from a distance. Further, these knotty spaces "require action and respect," but without a final "resolution" (p. 300).

In addition to stories like Bambi, direct encounters with deer further complexify the deer/settler relationship. Deer occupy an ambivalent place in the lives of many Vancouver Island children. As this article's opening alludes, children do have regular "friendly" encounters with deer through the window or the fence. The fence separates the children and educators from the deer, but it also allows for boundary blurrings and crossings that help to undo the categorical divisions it creates between colonized/colonizer and human/nonhuman. Children and educators alike enjoy their special excursions into the forest. These are now even easier through the gate that was installed during the playground renovations. Crossing the fence gives the children pleasure and a sense of novelty as they excitedly hope for encounters with the animals and trees they know live there, including deer. These fence crossings and encounters, as I argue later, have much potential for learning to live in postcolonial spaces.

But children's encounters with deer are not always as pleasant as the ones that take place at the child care centre. My doctoral student, Denise Hodgins, tells of her son being terrified of deer, specifically of an eventual deer attack. Wild animals are often feared in places like Vancouver Island. It's mostly cougars and bears that are feared, but reports of deer attacks have recently gained some momentum. It is common to hear in the news about the need to push deer out of urban areas as they become more and more accustomed to humans. Deer, the story goes, have become aggressive, not only toward humans but also toward pets.

Unlike Bambi or stories of deer attack, other encounters and stories compel me to look at the deer that pass the child care centre - and the deer that eat my roses, and the deer that are written about on hunting websites - from another vantage point. These stories raise different kinds of questions. A few months ago, I heard an interview on $\mathrm{CBC}$ radio with wildlife photographer Isobel Springett, who lives on Vancouver Island and has 
seeb a bond develop between two species. Springett's Great Dane, Kate, and a fawn called Pippin have become companion species. As Haraway (2008) would say, they have become political companions, messmates at the table who are engaged in a "dance linking kin and kind" and simultaneously making a mess out of categories (p. 17). What made this story a sensation in Canadian news is that Springett's actions of "domesticating" a wild animal are deemed unethical and illegal. A manager for the $\mathrm{BC}$ SPCA contends: "The susceptibility of a young fawn being imprinted like that has been well-documented, and it's really inappropriate because it sets the deer up for a hard life.... That deer is not going to have a wild life and it has no idea what predators are" (Clarke, 2011, para. 10). Springett has clarified that Pippin is not really a domesticated wild animal. She has learned to do what all wild animals do, but she has also learned to be in a close, loving relationship with Kate.

The story I want to tell about Kate and Pippin, though, is the one that many children on Vancouver Island are likely to encounter-Kate \& Pippin: An Unlikely Love Story, a picture book written by Springett's brother and illustrated by Springett herself. This tale begins with a fawn who lies on the ground for three days awaiting her mother, who never comes back. After listening to the fawn crying, Isobel carried her home, where Pippin and Kate encountered each other. After gazing at each other, "Kate gave the young deer a nuzzle and a lick" (p. 6) and a new and unlikely relationship began - a relationship in which both parties had to figure out what role to play and how to play it. The relationship changed both Kate and Pippin forever. At the end, Pippin returns to the forest and becomes an independent deer, but she never abandons her friend Kate, whom she visits regularly.

There are other stories like this one, as my colleague Shanne McCaffrey knows well. Her cat Orono and Nora, a deer, are getting to know each other in the old cedar grove in Shanne's back yard.

Haraway (2008) suggests that these stories can act as "microcosms" for thinking about both "how to inherit the history" of gaze with the deer and "how to shape becoming with them" in a potentially productive way (p. 105). Taylor (2011) warns us that these are not merely innocent stories of a cute deer with a caring dog. Instead, these stories bring species face to face to encounter their relationships head-on. They do not 
anthropomorphize deer and dogs "as infantilized humans in furry suits" like many children's stories do. Nor is this is "a domestication story that celebrates human mastery of nature" (p. 8). These stories, Taylor says, are "queer kin stor[ies] of knotty [deer/settler] co-existence of an unexpected and opportunistic kind" (p. 8) that allow us to think about cross-species relational grapplings that are the direct consequence of settler practices that disturb and endanger" lives (p. 8). Taylor suggests that, "by offering children the paradoxically mundane-yet-unusual details of such daily [multispecies] grapplings," these kinds of stories incite children to ask "What else is going on here?" and to be curious about the specific circumstances that bring species "together as queer kin in the first place" (p. 8). Simultaneously, these stories create spaces "for children to think about how they live with the differences of more-than-human others in their own commonworlds" (p. 8).

In the case of the children at the child care centre, the fence becomes, as Instone (2010) says, "a line of communication, not just a division": "Far from being stationary and fixed the fence is a dynamic space of contestation and interaction that activates all manner of work" (p. 97). The fence, as contested space, might "enact shifting relations between native/non-native, nature/culture" that are unknown (Instone, 2010, p. 98). The fence was constructed to prevent children's encounters with the "wild," the "outside." But as it stands there, it also presents a way to relate differently to the "wild" and the "native," and to the deer that inhabit the forest. Instone (2010), referring to fences that "protect” grasslands in Royal Park in Australia, writes:

Back at the fence we can understand a different relation than that of division and dualism, instead considering the fence as enacting an encounter, a space of conjunction and the possibility of a sideways movement across and along. From this perspective, other forms of connectivity more attuned to uncertainty, context, situation and multiplicity, more open to earthly others and lively encounters, may serve us better. (p. 110)

The fence is not just one thing; it has become entangled in human/nonhuman histories and networks without clear boundaries. Surprising possibilities might emerge from these entanglements from which we might learn new ways to live together in postcolonial 
spaces. As Instone says, these entanglements might "nudge us towards an ethics of cotransformation" that is full of uncertainties (p. 111).

\section{Human/nonhuman postcolonial encounters}

In this article I have endeavoured to tell stimulating and challenging stories of postcolonial entanglements between human and nonhuman species. These stories, I believe, are worth telling as we attempt to engage in nonhegemonic child and youth studies (de Finney et al., 2012). Threading Haraway's texts and learning from her entanglements with nonhuman species, I have outlined some ideas about what more might be required (Haraway, 2008, p. 42) when we think about how we might live our lives with children in postcolonial spaces in "responsible" ways. Haraway reminds us that every encounter makes us worldly and connects us with layers and layers of local and global histories and webs. Once we have come face to face with the species we live with, "obligations and possibilities for response change" (p. 97). Haraway puts it beautifully:

Like it or not, flesh-to-flesh and face-to-face, I have inherited these histories through touch [or vision] with my dogs, and my obligations in the world are different because of that fact. That's why I have to tell these stories - to tease out the personal and collective response required now, not centuries ago. Companion species cannot afford evolutionary, personal, or historical amnesia. (p. 98)

Here, I believe, are lessons for those of us working with children. Perhaps we can begin to pay attention to children's encounters with nonhuman species so that we can find ways to respond to histories of colonization. "How are we going to respond to these mundane encounters?" might be the question we need to ask and grapple with.

If we tell these mundane stories, Haraway writes, we might begin to remember other stories - "stories about immigration, indigenous worlds, work, hope, love, play; and the possibility of cohabitation through reconsidering sovereignty and ecological developmental naturecultures" (p. 98). Deborah Bird Rose (2004) refers to an "ethics for decolonization" as one that "work[s] with harm, twisting violence back into flourishing and life-affirming relationships" (p. 8). This is an ethics about connections that is "situated in bodies and in time and in place" (Rose, 2004, p. 8). Rose writes: 
The ethical challenge of decolonization illuminates a ground of powerful presence. Against domination it asserts relationality, against control it asserts mutuality, against hyperseparation it asserts connectivity, and against claims that rely on an imagined future it asserts engaged responsiveness in the present. (p. 213)

If we tell these situated stories and pay attention to how we are entangled in a web of histories, we may begin to see our relationships with children differently. If we ourselves or children themselves are not seen as the centre of our troubles, but instead we become more worldly, then we might find possibilities for new worlds and new relations to emerge. Looking at the deer who visit our playgrounds and following the stories that connect and entangle us with them cannot but make us "more worldly, more enmeshed in webs of history that demand response today" (p. 100). These encounters generate meanings and generate us and the deer and multiple species. More importantly, these encounters coshape us all and our histories. There is nothing simple about these entanglements. No generalizations can be made as to how we practice, what we do, or how we respond. Each encounter requires a different kind of attention. There are no shortcuts for any of us. Haraway (2008) writes: "There is no happy ending to offer, no conclusion to this ongoing entanglement, only a sharp reminder that anywhere one really looks actual living [nonhumans] are waiting to guide humans into contested worldings" (p. 39).

We need to figure out, together, how we want to live as heterogeneous species that are now entangled in colonized common worlds. 


\section{References}

Blaise, M. (2011, October). Grappling with contact zones of species assemblages: Dogs/humans, children/adults. Paper presented at $19^{\text {th }}$ Reconceptualising Early Childhood Education Conference "Politics of Care: Sharing Knowledges, Love and Solidarity," University of East London, England.

British Columbia Ministry of Environment, Lands, and Parks. (n.d.). Mule and blacktailed deer in British Columbia. Retrieved from: http://www.env.gov.bc.ca/wld/documents/muledeer.pdf

Castaneda, C. (2002). Figurations: Child, bodies, worlds. London, UK: Duke University Press.

Clarke, B. (2011, September 20). A dog and the deer who's dear to her become Internet sensations. The Globe and Mail. Retrieved from:

http://www.theglobeandmail.com/news/national/british-columbia/a-dog-and-the-deerwhos-dear-to-her-become-internet-sensations/article2173831/

Cook, P., \& Young, J. (2004). Face-to-face with children. Journal of Curriculum Studies, $36(3), 341-360$.

de Finney, S., Dean, M., Loiselle, E., \& Saraceno, J. (2011). All children are equal, but some are more equal than others: Minoritization, structural inequities, and social justice praxis in residential care. International Journal of Child, Youth and Family Studies, 3 \& 4: 361-384.

de Finney, S., Gharabaghi, K., Little, J. N., \& Skott-Myhre, H. (2012). Conversations on "Conversing in Child and Youth Care." International Journal of Child, Youth and Family Studies, 2 \& 3: 128-145.

Foucault, M. (1977). Discipline and punish: The birth of the prison. New York, NY: Vintage.

Giugni, M. (2011, October). Breakfast 'with' the chicken: Worldliness as another kind of activism in early childhood. Paper presented at $19^{\text {th }}$ Reconceptualising Early 
Childhood Education Conference "Politics of Care: Sharing Knowledges, Love and Solidarity," University of East London, England.

Government of British Columbia. (2008). British Columbia early learning framework.

Victoria, BC: Ministry of Education.

Haraway, D. (1995). Otherwordly conversations, terran topics, local terms. In V. Shiva \& N. Moser (Eds.), Biopolitics: A feminist and ecological reader on biotechnology (pp. 69-92). London, UK: Palgrave Macmillan.

Haraway, D. (1997).Modest_witness@Second_Millennium.FemaleMan@_Meets_Onco Mouse ${ }^{\mathrm{TM}}$ : Feminism and technoscience. New York, NY: Routledge.

Haraway, D. (2008). When species meet. Minneapolis, MN: University of Minnesota Press.

Hastings, A. W. (1996). 'Bambi and the hunting ethos. Journal of Popular Film and Television, 24: 53-59. Retrieved from: http://www.questia.com/PM.qst?a=o\&d=94295827

Instone, L. (2010). Encountering native grasslands: Matters of concern in an urban park. Australian Humanities Review, 49, 91-117.

Jiwani, J. (2006). Discourses of denial: mediations of race, gender and violence. Vancouver, BC: UBC Press.

Kasturi, S. (2002). Constructing childhood in a corporate world: Cultural studies, childhood, and Disney. In G. Cannella \& J. Kincheloe (Eds.), Kidworld: Childhood studies, global perspectives and education (pp. 39-58). New York, NY: Peter Lang.

Levinas, E. (1969). Totality and infinity: an essay on exteriority. Pittsburg. PA: Duquesne University Press.

Nxumalo, F., Pacini-Ketchabaw, V. \& Rowan, C. (2011). Lunch time at the child care centre: Neoliberal assemblages in early childhood education. Journal of Pedagogy, 2(2), 195-223.

Outdoor Adventures Network. (2012). Deer habitat. Retrieved from: http://www.myoan.net/huntingart/deer_habit.html 
Pacini-Ketchabaw, V. (2007). Child care and multiculturalism: A site of governance marked by flexibility and openness. Contemporary Issues in Early Childhood, 8(3), $222-232$.

Pacini-Ketchabaw, V. (in press). Acting with the clock: Clocking practices in early childhood. Contemporary Issues in Early Childhood Education.

Pacini-Ketchabaw, V. (submitted). Crafting new relationships in child and youth care: Human-nonhuman encounters. H. Skott-Myhre, K. Gharabaghi, \& T. Garfat (Eds.), With children.

Pacini-Ketchabaw, V., Kummen, K., \& Thompson, D. (in press). Making developmental knowledge stutter and stumble: Continuing pedagogical explorations with collective biography. In V. Pacini-Ketchabaw \& L. Prochner (Eds.), Resituating Canadian early childhood education. New York, NY: Peter Lang.

Pacini-Ketchabaw, V., with Nxumalo, F. (2010). A curriculum for social change: experimenting with politics of action or imperceptibility. In V. Pacini-Ketchabaw (Ed.), Flows, rhythms, and intensities of early childhood education curriculum (pp. 133-154). New York, NY: Peter Lang.

Pacini-Ketchabaw, V., White, J., \& Armstrong de Almeida, A. E. (2006). Racialization in early childhood: A critical analysis of discourses in policies. International Journal of Educational Policy, Research, and Practice: Reconceptualizing Childhood Studies, $7(1), 95-113$.

Razack, S., Smith, M., \& Thobani, S. (2010). States of race: Critical race feminism for the 21st century. Toronto, ON: Between the Lines.

Rose, D. B. (2004). Reports from a wild country: Ethics for decolonization. Sydney, AUS: University of New South Wales Press.

Skott-Myhre, K. (2012). Nomadic youth care. International Journal of Child, Youth, and Family Studies, 3(2/3), 300-315.

Springett, M. (2011). Kate \& Pippin: An unlikely love story. Toronto, ON: Penguin. 
Taylor, A. (2011, October). Haraway's method: Earthy grapplings and worldly visions. Paper presented at 19th Reconceptualising Early Childhood Education Conference "Politics of Care: Sharing Knowledges, Love and Solidarity," University of East London, England.

Taylor, A., Blaise, M., \& Giugni, M. (2013). Haraway’s “bag lady story-telling”: Relocating childhood and learning within a "post-human landscape." Discourse: Studies in the Cultural Politics of Education, 34(1).

Tobin, J. (2000). 'Good guys don't wear hats': Children's talk about the media. New York, NY: Teachers College Press. 